\title{
The Banks Profitability and Economic Freedom Quality: Empirical Evidence from Arab Economies
}

\author{
Omar Ghazy Aziz \\ School of Business and Law, University of Central Queensland, Australia ${ }^{1}$ \\ Emailo.aziz@cqu.edu.au \\ Julie Knutsen \\ School of Business and Law, University of Central Queensland, Australia
}

\begin{abstract}
This study empirically examines the impact of economic freedom quality and global financial crisis on the banking sector profitability in the Arab region. The analysis is performed by employing system GMM estimation in panel data comprising of 14 Arab countries over the period 1985-2016. The study constructed an economic freedom index based on the economic freedom indicators. The findings indicate that greater economic freedom has positively influenced the profitability of the Arab banking sector. The results also suggest that the more profitable banks are those that have lower operating expenses against asset and income, better capitalized, more diversified and concentrated at economies having growth in the GDP. Furthermore, the global financial crisis in 2008 negatively impacted the profits of Arab banks.
\end{abstract}

JEL classification: G210, G280, C23.

Key words: Profitability, Economic freedom, Global financial crisis, Arab economies.

\section{INTRODUCTION}

During the last decade, deposit growth rates in a number of Arab countries were weakened by the downward trend of global oil prices, however the banking sectors are continuing to perform positively in this region. In 2008, the financial crisis and global recession have tested the strength of the financial institutions and regulatory structures in the Arab region as well as the world. In the Arab region, several developments are implemented to improve the infrastructure of the banking sectors including legislation and regulation to fulfil latest Basel standards, particularly on liquidity risk, enhancing the governance and transparency and set up measurements to be more responsive to latest international developments ${ }^{2}$. Before the global financial crisis, the development in economic freedom in the Arab region has remained stable and almost steady, witnessed increasingly as very close to the same rate as the world average. However, the recent

Corresponding author: Dr. Omar Aziz, email to: o.aziz@cqu.edu.au. Postal address: School of Business and Law, University of Central Queensland, 400 Kent Street, Sydney, NSW 2000, Australia.

2 Arab Monetary Fund. (2016). 
figure of the average score of the Arab region has exhibited a slight but noticeable decline and this is a considerable achievement given the challenges that the region has faced in past years ${ }^{3}$.

Considering these major developments in the Arab region, there is no doubt that could be reflected on the profitability and performance of the banking sectors that are operating in the region. As a sound and profitable banking sector is better able to contribute to the stability of the financial system and diversify the economy, which are governments' goals, therefore, examining the determinants of bank profitability is essential to the policies makers and banks managers in this transformational business environment.

Numerous researches on banking sectors mainly focus on the regions of North and South America, East Europe, Africa and Asia (Demirguc-Kunt et al., 2000, Berger and Mester, 2003, Francis, 2013, Islam and Nishiyama, 2016, Logan, 2016 and Combey and Togbenou, 2017). There is little attention in the research on the Arab banking sector, especially, on the nexus between economic freedom and profitability; this could be due to lack of reliable data compared with other regions. There are banks profitability studies that focus only on Gulf Cooperation Council countries (GCC), the Middle East and North Africa (MENA) region or an individual Arab country ${ }^{4}$. Although these studies show that it is possible to conduct a meaningful analysis of bank profitability, there are few issues not dealt with sufficiently and estimated results could be biased (Al-Omar and Al-Mutairi, 2008, Bennaceur and Goaied, 2008, Amba and Almukharreq, 2013, Mokni et al., 2014, Alkhazaleh and Almsafir, 2014, Murthy Y and Al-Muharrami, 2014, Caporale et al., 2016, Ghosh, 2016, Abdullah et al., 2017). First, the literature principally considers determinants of profitability with no comprehensive selection for the variables set, countries in the sample under investigation and the short time dimension of the panels used in the estimation. Second, the results could be inconsistent due to the use of the econometric methodology that does not adequately account for some features of bank profits (e.g. persistence) or omitted variables. In addition, since the countries in the sample have different features, thus, the data in the panels may raise the issue of country-specific effects, hence, using an estimation that overcomes this problem is essential.

This study fills in the gap and contributes to the existing literature by taking into account the economic freedom while empirically investigates the determinants of banking sector profitability in 14 Arab economies ${ }^{5}$ over the period from 1985-2016 and using a wide range of variables including bank-specific factors with other important variables such as global financial crisis (GFC). For econometric analysis, this study employs system GMM (Arellano-Bover/BlundellBond) techniques to deal with issues related to endogeneity, omission of relevant variables, measurement error, sample selectivity, or simultaneity. The study adequately addresses the issue of unit root properties of the variables. What makes this study have a singularity is that it develops an overall index from the five individual indicators of economic freedom by computing their weighted average, taking factor loadings in principal components analysis (PCA) as weights, to avoid testing partially correlated indices against each other, which makes this study have advantages compared to others.

This comprehensive empirical analysis attempts to answer the following research questions: What is the impact of economic freedom on the banking sector profitability in the Arab region? Do the efficient protection of privately-owned property, even-handed enforcement of contracts, refrain of creating barriers to trade, and relying fully on markets mechanisms play an important role for the banking profitability? How important is the bank size, credit risk and operation cost

The Economic Freedom of the World Reports (2007, 2014 and 2017).

The League of Arab State comprises 22 countries (Algeria, Bahrain, Comoros, Djibouti, Egypt, Iraq, Jordan, Kuwait, Lebanon, Libya, Mauritania, Morocco, Oman, Palestine, Qatar, Saudi Arabia, Somalia, Sudan, Syria, Tunisia, UAE and Yemen).

This study focuses on 14 countries due to data limitation, they are: Algeria, Bahrain, Egypt, Jordan, Kuwait, Lebanon, Morocco, Oman, Qatar, Saudi Arabia, Syrian, Tunisia, United Arab Emirates, and Yemen. 
to the profitability for the banks that are operating in the Arab region? What is the impact of GFC along with other economic variables on Arab bank profitability?

This paper is formulated as follows: Section 2 describes the methodology. Section 3 presents the summary statistics and correlation. Section 4 discusses the empirical results. Section 5 concludes and provides policy implications.

\section{METHODOLOGY}

\subsection{Data and Variables}

For the empirical analyses, this study utilises panel data of 14 Arab countries over the period 1985-2016: Algeria, Bahrain, Egypt, Jordan, Kuwait, Lebanon, Morocco, Oman, Qatar, Saudi Arabia, Syrian, Tunisia, United Arab Emirates, and Yemen. Appendix Table A.1 provides information about the sources of data and definition. This study constructs a variable to capture the economic freedom quality by calculating a quality index using principal components analysis (PCA) technique.

\subsubsection{Bank Profitability}

The study uses return on assets ratio as a measure for bank profitability. The ratio of return on assets shows the profit earned per dollar of assets and, most importantly, reflects the management ability to utilize the bank's financial and real investment assets to generate profits, thus it is encompassing both management decisions and policy objectives (Sufian and Habibullah, 2009). This study selects to focus on return on assets ratio as measurement for profitability, rather than the return on equity ratio because as Admati et al. (2013) states the use of return on equity becomes problematic when comparisons are made across different capital structures. The data for return on assets is from the World Bank's Global Financial Development Database.

\subsubsection{Economic Freedom Quality}

In order to measure the economic freedom quality of the Arab region, this study employs data from the Fraser Institute. Economic freedom ${ }^{6}$ measures the degree to which the policies and institutions of countries are supportive of economic freedom. There are many channels that the economic freedom positively impacts bank profitability. First, economic freedom strongly promotes investment and the coemption between firms in the economy, as a result, this increases the lending activities and leads to more income for banks (Al Ismaily and Al-Busaidi, 2017). Second, greater economic freedom attracts more foreign companies and financial institutions, thus, better income diversification and risk minimization for the banking system. Third, better economic freedom can enhance the productivity of overall businesses that boost the economic growth, this in turn is positivity reflected in banking profitability (Asteriou et al., (2016).

The economic freedom has five indicators including the size of government, legal system and property rights, access to sound money, freedom to trade internationally, and regulation of credit, labour, and business ${ }^{7}$. These help to measure the contribution of economic institutions more

In order to receive a high economic freedom rating, a country must provide secure protection of privately-owned property, even-handed enforcement of contracts, and a stable monetary environment. It also must keep taxes low, refrain from creating barriers to both domestic and international trade, and rely more fully on markets rather than government spending and regulation to allocate goods and resources (Gwartney et al., 2018).

Each indicator has a different number of sub-components. Size of government indicator consists of average number of the sub-components: government consumption as a share of total consumption, transfers and subsidies as a share of GDP, government enterprises' production as share of total output and top of marginal tax rates. Legal system and property rights indicator is based on the levels of judicial independence, impartial courts, protection of property rights, military interference in rule of law and politics, integrity of the legal system, legal enforcement of contracts, regulatory restrictions on the sale of real property, reliability of police and business costs of crime. Access to sound money indicator is money 
thoroughly and to distinguish it from political, climatic, locational, cultural, and historical factors as determinants of growth and development (Gwartney et al., 2014). To obtain the overall index, the study calculates a weighted average of the five individual indicators of economic freedom, taking factor loadings in principal components analysis (PCA) as weights ${ }^{8}$. Higher values reflect better economic freedom institutional quality.

\subsubsection{Bank-specific characteristics and others Control Variables}

The study includes key control variables for the model to reflect the determinants of bank profitability as per the existing literature to overcome the lack of consistency in the selection of bank and industry specific characteristics. To address this issue, the study selects several bankspecific and macroeconomic variables to represent a comprehensive set of control variables for the test.

For the bank-specific variables first is the bank size which is the deposit money bank assets scaled by gross domestic production. A larger size is expected to have a positive effect on bank performance due to the benefits obtained from increase in profitability and service quality (Lema, 2017). Second, bank liquidity is the ratio of loans as a share of total deposits. This ratio shows the extent that the bank has lent its deposits. Bank loans are assumed to be the main source of profitability and are expected to affect profitability positively. If more deposits are transformed into loans, the interest margin and profit will be higher. However, it could be negatively impacting the profitability during the weak economic conditions that are likely causing the borrowers to default on loans. Higher loan-deposit ratio could lead to higher credit risk and higher nonperforming loans, resulting in lower returns with liquidity problems (Spathis et al., 2002, Sufian and Kamarudin, 2012).

Third, the overhead cost is the ratio of operating expenses of a bank as a share of the value of all assets held. This cost represents total amount of wages and salaries, as well as the costs of running branch office facilities. Since the reduction of overhead expenses will raise profits, the ratio of these expenses to total assets is expected to be negatively related to profitability and can reflect the level of a bank's management efficiency (Athanasoglou et al., 2008, ElKelish and Tucker, 2015). On the other hand, the literature is also suggesting that high profits earned by banks could be attributed to the higher payroll expenditures paid to more productive human capital (Sufian and Habibullah, 2010). Thus, the coefficient of this variable could be negative or positive.

Fourth, bank concentration is the assets of the five largest banks as a share of the assets of all commercial banks in a given country. This is a common variable that is used as a proxy for market structure to represent the banking sector's concentration. According to the structure-conductperformance (SCP) hypothesis, higher concentration may lead to greater bank efficiency because maybe the banks in a highly concentrated market tend to collude, and therefore earn monopoly profits. However, this state of collusion may have a negative impact on smaller banks profitability when they are facing tougher competition that result from this monopoly condition. On the other hand, if the industry concentration results from tougher inter-bank competition, the impact of the market structure might turn negative. Thus, the theoretical relationship between concentration and bank performance is ambiguous and to be answered empirically (Berger, 1995, Garza-García, 2012, Sufian and Kamarudin, 2012, Chan et al., 2015).

\footnotetext{
supply growth rate, standard deviation of inflation, the rate of inflation and freedom to own foreign currency bank accounts. Freedom to trade internationally indicator is based on the levels of tariffs rates, regulatory trade barriers, black-market exchange rates and controls of the movement of capital and people. Regulation indicator is based on the freedom levels of credit market, labour market and business activities regulations (Gwartney et al., 2018).

8 This way maximises variation and avoid testing partially correlated indices against each other. Using PCA lets the structure of the data determine how components are pooled to form separate indices instead of forcing a specific organisation on the data (Busse and Groizard, 2008). For more about PCA see: Kuhn and Johnson, 2013 and James et al., 2015).
} 
Fifth, income diversification is a bank's income that has been generated by noninterest related activities as a percentage of total income. Non-traditional banking activities enable banks to offer wide range of products and services and spread the lending risk across a large number of asset categories, thereby reducing monitoring costs. It is expected to have a positive impact on bank profitability (Reddy, 2011).

Sixth, credit risk is the ratio of defaulting loans to total gross loans. Increasing in the expenses of loan or interest payment loss can reduce the overall profitability levels (Sufian, 2012). The percentage of credit risk may increase after periods of increased lending often. When bank managers are under the pressure of a competitive market, they maybe employ less rigorous lending standards to satisfy short-term profit targets which could cause a negative impact on profitability (Liu and Wilson, 2010).

Seventh, cost efficiency is operating expenses of a bank as a share of operating income. It measures the impact of operating efficiency on bank profitability. Due to the fact that cost minimization leads to profit maximization, the most cost-efficient banks produce services and products at lower costs. A lowering of a bank's cost ratio and hence higher managerial efficiency is expected to increase profitability if bank managers are choosing highly profitable assets and low-cost liabilities. The superior management and technology factors can be efficiently utilized by the banks to increase the profit. This ratio is expected to negatively affect bank profitability (Liu and Wilson, 2010, Djalilov and Piesse, 2018).

Eighth, capital strength is the ratio of bank capital and reserves to total assets. Strong capital structure is essential to provide additional strength to the bank during unstable macroeconomic conditions and soundness of higher management quality. In addition, lower capital ratios in banking imply higher leverage and risk due to the greater need to go for external funding, which in turn increases their borrowing costs and lowers their profit. Thus, the relatively better capitalized banks should exhibit higher profitability level (Rekik and Kalai, 2018).

For the macroeconomic variables that are encompassed by this study are the percentage growth of gross domestic production (GDP), inflation rate is the annual percentage change in consumer price index (CPI), financial development is bank domestic credit to private sector as percentage of GDP banking, global financial crisis (GFC) is dummy variable for the presence of global financial crisis in 2008 which takes the value of 1 for the years 2009 to 2016 zero otherwise (Akinkunmi, 2017, Turgutluk, 2014).

The data on bank size, liquidity, overhead cost, bank concentration, income diversification, credit risk, cost efficiency, capital strength and financial development are from the World Bank's Global Financial Development Database. The data on GDP growth and inflation rate are from the World Bank's World Development Indicators. The data on global financial crisis (GFC) is the author's calculation.

\subsection{Econometric Estimation}

This study employs the system GMM estimator of Arellano-Bover/ Blundell-Bond. It takes into account the presence of unobserved country-specific effects and any possible bias of omitted variables that are persistent over time. The empirical model is as follows:

$$
y_{i t}=\delta y_{i, t-1}+\beta x_{i t}+u_{i t} \quad i=1, \ldots, N \quad t=2, \ldots, T
$$

where $y_{i t}$ is return on assets, $\delta$ is a scalar, $x_{i t}$ is a $1 \times K$ vector of explanatory variables and $\beta$ is a $K \times 1$ vector of parameters to be estimated. The error term $u_{i t}$ is composed of an unobserved effect and time-invariant effect $\mu_{i}$ and random disturbance term $v_{i t}$. 


$$
u_{i t}=\mu_{i}+v_{i t}
$$

where $\mu_{i} \sim \operatorname{IID}\left(0, \sigma_{\mu}^{2}\right)$ and $v_{i} \sim \operatorname{IID}\left(0, \sigma_{v}^{2}\right)$ independent of each other and among themselves. The dynamic panel data regressions described in above equations (1) and (2) are characterized by two sources of persistence over time i.e. autocorrelation due to the presence of a lagged dependent variable $y_{i, t-1}$ among the regressors and individual effects characterizing the heterogeneity among the individuals $\mu_{i}$.

Arellano and Bond (1991) suggest first-differencing Equation (1) to eliminate the unobserved effect since the disturbance $\mu_{i}$ does not vary with time as follow:

$$
y_{i t}-y_{i, t-1}=\delta\left(y_{i, t-1}-y_{i, t-2}\right)+\beta\left(x_{i t}-x_{i, t-1}\right)+\left(v_{i t}-v_{i, t-1}\right)
$$

GMM helps overcome endogeneity by using lagged-values of the explanatory variables as instruments. However, first-differencing generates a new statistical issue that the constructed differenced error term $v_{i t}$ is now correlated with the dependent lagged variable $y_{i, t-1}-y_{i, t-2}$ which is included as a regressor. As a solution, Arellano and Bover (1995) and Blundell and Bond (1998) proposed a system GMM estimator that uses moment conditions in which lagged differences (Equation 3) are used as instruments for the level equation (Equation 1) in addition to the use of moment conditions of lagged levels as instruments for the differenced equation. However, the use of system GMM depends on two conditions, first is the validity of these additional instruments, second is the absence of second-order autocorrelation for . To assess these two conditions, Arellano and Bond (1991) and Arellano and Bover (1995) propose the Sargan test of over-identification and the Arellano-Bond AR (2) for autocorrelation. The Sargan test of over-identification tests the validity of the instruments. When the Sargan test is insignificant, this means the instruments are not correlated with the residuals; thus, these instruments are valid. Arellano-Bond AR (2) autocorrelation tests for the absence of second-order autocorrelation and its result must be insignificant to indicate that there is no second-order autocorrelation in the residuals.

\section{SUMARY STATISTICS, CORRELATION AND STATIONARITY TESTS}

Table 1 illustrates summary statistics for variables. Economic freedom quality variable has lowest mean of -0.176 , while return on assets variable has the lowest standard deviation of 0.177 . The inflation variable has highest mean of 96.199 , while the liquidity variable has highest standard deviation of 38.525 .

Table 1.

Summary Statistics

\begin{tabular}{lccccc}
\hline \multicolumn{1}{c}{ Variables } & Obs. & Mean & Std. Dev. & Min & Max \\
\hline Return on assets & 290 & 1.261 & 0.177 & 1.076 & 1.456 \\
Economic freedom & 174 & 0.176 & 0.860 & -3.842 & 2.875 \\
Bank size & 391 & 1.391 & 8.484 & -88.996 & 31.914 \\
Liquidity & 428 & 77.471 & 38.525 & 15.016 & 199.772 \\
Overhead cost & 291 & 1.633 & 0.625 & 0.060 & 6.460 \\
Bank concentration & 263 & 83.154 & 13.831 & 48.180 & 100.000 \\
Income diversification & 243 & 0.398 & 5.895 & -22.682 & 25.000 \\
Credit risk & 188 & 9.245 & 5.841 & 2.000 & 19.300 \\
\hline
\end{tabular}




\begin{tabular}{lcccrr}
\hline \multicolumn{1}{c}{ Variables } & Obs. & Mean & Std. Dev. & Min & Max \\
\hline Cost efficiency & 258 & 43.271 & 12.189 & 22.716 & 146.853 \\
Capital strength & 160 & 9.872 & 2.961 & 5.600 & 13.700 \\
GFC & 448 & 0.250 & 0.433 & 0.000 & 1.000 \\
GDP growth & 410 & 4.174 & 6.396 & -42.451 & 38.200 \\
Inflation & 382 & 96.199 & 12.344 & 82.001 & 111.478 \\
Financial development & 425 & 42.840 & 24.109 & 3.014 & 107.246 \\
\hline \hline
\end{tabular}

Note: Obs. is observation. Mean is mean. Std. Dev. is standard deviation. Min is minimum. Max is maximum. Refer to Appendix Table A.1 for definition of variables. Return on assets is the banks net income to total assets (percentage). Bank size is deposit money bank assets scaled by gross domestic production. Liquidity is the ratio of loans as a share of total deposits. Overhead cost is the ratio of operating expenses of a bank as a share of the value of all assets held. Bank concentration is the assets of the five largest banks as a share of the assets of all commercial banks in a given country. Income diversification is bank's income that has been generated by noninterest related activities as a percentage of total income. Credit risk is the ratio of defaulting loans to total gross loans. Cost efficiency is operating expenses of a bank as a share of operating income. Capital strength is the ratio of bank capital and reserves to total assets. Global financial crisis is dummy variable for the presence of global financial crisis in 2008. Global financial crisis (GFC) is dummy variable for the presence of global financial crisis in 2008. GDP growth is the percentage growth of gross domestic production (GDP). Inflation rate is the annual percentage change in consumer price index (CPI). Financial development is bank domestic credit to private sector as percentage of GDP.

Table 2 illustrates the correlation matrix between the variables. There is high correlation between several variables: overhead cost and cost efficiency (0.806); bank size and capital strength (0.523); credit risk and capital strength (-0.689); cost efficiency and capital strength $(-0.530)$; GFC and inflation (0.681). The study will not include highly correlated variables together in the same model.

Table 2.

Correlation Matrix

\begin{tabular}{|c|c|c|c|c|c|c|c|c|c|c|c|c|c|c|}
\hline Variables & 1 & 2 & 3 & 4 & 5 & 6 & 7 & 8 & 9 & 10 & 11 & 12 & 13 & 14 \\
\hline 1. Return on assets & 1 & & & & & & & & & & & & & \\
\hline 2. Economic freedom & -0.10 & 1 & & & & & & & & & & & & \\
\hline 3. Bank size & -0.11 & -0.06 & 1 & & & & & & & & & & & \\
\hline 4. Liquidity & 0.26 & -0.02 & 0.11 & 1 & & & & & & & & & & \\
\hline 5. Overhead cost & -0.30 & 0.24 & -0.07 & 0.17 & 1 & & & & & & & & & \\
\hline 6. Bank concentration & 0.41 & 0.25 & -0.06 & 0.15 & -0.20 & 1 & & & & & & & & \\
\hline 7. Income diversification & 0.01 & 0.16 & -0.06 & 0.12 & 0.17 & 0.12 & 1 & & & & & & & \\
\hline 8. Credit risk & -0.58 & 0.28 & -0.11 & -0.38 & 0.29 & -0.35 & 0.03 & 1 & & & & & & \\
\hline 9. Cost efficiency & -0.59 & 0.17 & 0.05 & -0.06 & 0.80 & -0.39 & 0.04 & 0.51 & 1 & & & & & \\
\hline 10. Capital strength & 0.57 & 0.13 & -0.07 & 0.48 & -0.25 & 0.52 & 0.09 & -0.68 & -0.53 & 1 & & & & \\
\hline 11. GFC & 0.01 & -0.41 & 0.10 & 0.10 & -0.29 & -0.16 & -0.12 & -0.34 & -0.18 & 0.19 & 1 & & & \\
\hline 12. GDP growth & 0.24 & 0.09 & -0.48 & -0.11 & -0.05 & 0.09 & 0.08 & -0.08 & -0.04 & -0.07 & -0.29 & 1 & & \\
\hline 13. Inflation & 0.03 & -0.41 & -0.06 & -0.05 & -0.12 & -0.04 & -0.13 & -0.39 & -0.12 & 0.11 & 0.68 & -0.07 & 1 & \\
\hline 14. Financial development & -0.20 & 0.07 & 0.23 & 0.21 & -0.05 & 0.01 & 0.08 & -0.16 & 0.10 & 0.08 & -0.05 & -0.02 & -0.08 & 1 \\
\hline
\end{tabular}

Note: The column number corresponds with the row titles. Refer to Appendix Table A.1 for definition of variables. Return on assets is the banks net income to total assets (percentage). Bank size is deposit money bank assets scaled by gross domestic production. Liquidity is the ratio of loans as a share of total deposits. Overhead cost is the ratio of operating expenses of a bank as a share of the value of all assets held. Bank concentration is the assets of the five largest banks as a share of the assets of all commercial banks in a given country. Income diversification is bank's income that has 
been generated by noninterest related activities as a percentage of total income. Credit risk is the ratio of defaulting loans to total gross loans. Cost efficiency is operating expenses of a bank as a share of operating income. Capital strength is the ratio of bank capital and reserves to total assets. Global financial crisis is dummy variable for the presence of global financial crisis in 2008. Global financial crisis (GFC) is dummy variable for the presence of global financial crisis in 2008. GDP growth is the percentage growth of gross domestic production (GDP). Inflation rate is the annual percentage change in consumer price index (CPI). Financial development is bank domestic credit to private sector as percentage of GDP.

Table 3 shows the panel unit root test Levin-Lin-Chu (LLC), Im-Pesaran-Shin (IPS) and Fisher-type test (Fisher) results. The null hypothesis of unit root is rejected for the variables; in other words, the variables are stationary.

Table 3.

Panel Unit Root Tests

\begin{tabular}{|c|c|c|c|c|}
\hline Variables & LLC & IPS & Fisher & Decision \\
\hline Return on assets & $\begin{array}{l}-3.050^{*} \\
(0.001)\end{array}$ & $\begin{array}{c}-2.075^{*} \\
(0.019)\end{array}$ & $\begin{array}{l}-6.941^{*} \\
(0.000)\end{array}$ & Stationarity \\
\hline Economic freedom & $\begin{array}{l}-6.089^{*} \\
(0.000)\end{array}$ & $\begin{array}{l}-3.961^{*} \\
(0.000)\end{array}$ & $\begin{array}{l}-7.771^{*} \\
(0.000)\end{array}$ & Stationarity \\
\hline Bank size & $\begin{array}{l}-6.701^{*} \\
(0.000)\end{array}$ & $\begin{array}{l}-6.947^{*} \\
(0.000)\end{array}$ & $\begin{array}{l}-6.915^{*} \\
(0.000)\end{array}$ & Stationarity \\
\hline Liquidity & $\begin{array}{l}-3.053^{*} \\
(0.001)\end{array}$ & $\begin{array}{l}-2.929^{*} \\
(0.001)\end{array}$ & $\begin{array}{l}-7.839^{*} \\
(0.000)\end{array}$ & Stationarity \\
\hline Overhead cost & $\begin{array}{l}-2.734^{*} \\
(0.003)\end{array}$ & $\begin{array}{l}-2.431^{*} \\
(0.007)\end{array}$ & $\begin{array}{l}-7.218^{*} \\
(0.000)\end{array}$ & Stationarity \\
\hline Bank concentration & $\begin{array}{l}-2.687^{*} \\
(0.003)\end{array}$ & $\begin{array}{c}-2.001^{* *} \\
(0.022)\end{array}$ & $\begin{array}{l}-5.735^{*} \\
(0.000)\end{array}$ & Stationarity \\
\hline Income diversification $^{a}$ & $\begin{array}{c}-11.117^{*} \\
(0.000)\end{array}$ & $\begin{array}{l}-6.886^{*} \\
(0.000)\end{array}$ & $\begin{array}{c}-10.006^{*} \\
(0.000)\end{array}$ & Stationarity \\
\hline Credit risk & $\begin{array}{c}-1.844^{* *} \\
(0.032)\end{array}$ & $\begin{array}{l}-3.073^{*} \\
(0.001)\end{array}$ & $\begin{array}{l}-6.140^{*} \\
(0.000)\end{array}$ & Stationarity \\
\hline Cost efficiency & $\begin{array}{l}-3.289^{*} \\
(0.000)\end{array}$ & $\begin{array}{l}-4.808^{*} \\
(0.000)\end{array}$ & $\begin{array}{l}-8.622^{*} \\
(0.000)\end{array}$ & Stationarity \\
\hline Capital strength & $\begin{array}{c}-0.135^{* *} \\
(0.056)\end{array}$ & $\begin{array}{c}-1.945^{* *} \\
(0.025)\end{array}$ & $\begin{array}{l}-5.125^{*} \\
(0.000)\end{array}$ & Stationarity \\
\hline GFC & $\begin{array}{l}-2.125^{*} \\
(0.000)\end{array}$ & $\begin{array}{c}-1.498^{* * *} \\
(0.067)\end{array}$ & $\begin{array}{c}-1.863^{* *} \\
(0.031)\end{array}$ & Stationarity \\
\hline GDP growth & $\begin{array}{l}-4.956^{*} \\
(0.000)\end{array}$ & $\begin{array}{l}-8.794^{*} \\
(0.000)\end{array}$ & $\begin{array}{c}-11.658^{*} \\
(0.000)\end{array}$ & Stationarity \\
\hline Inflation & $\begin{array}{l}-5.689^{*} \\
(0.000)\end{array}$ & $\begin{array}{l}-2.303^{*} \\
(0.010)\end{array}$ & $\begin{array}{l}-6.358^{*} \\
(0.000)\end{array}$ & Stationarity \\
\hline Financial development & $\begin{array}{c}-1.528^{* *} \\
(0.053)\end{array}$ & $\begin{array}{l}-2.167^{*} \\
(0.015)\end{array}$ & $\begin{array}{l}-7.762^{*} \\
(0.000)\end{array}$ & Stationarity \\
\hline
\end{tabular}

Note: LLC is Levin-Lin-Chu (Adjusted t*), IPS is Im-Pesaran-Shin (w-t-bar) and Fisher is Fisher-type (Invers normal Z). For LLC the null hypothesis: panels contain unit root, while the alternative Ha: panels are stationarity. IPS: all panels contain unit root, Ha: some panels are stationarity. Fisher: all panels contain unit roots, Ha: at least one panel is stationarity. Therefore, LLC tests for common unit root, while IPS and Fisher tests for individual unit roots. P-values in brackets. ${ }^{*},{ }^{* *},{ }^{* * *}$ denote significance at the 1 per cent, 5 per cent and 10 per cent levels, respectively for p-values. Refer to Appendix Table A.1 for definition of variables. The measurement for stationarity is if the variable passes the three tests, then it is considered stationary. ${ }^{\text {a }}$ : first difference state. 


\section{EMPIRICAL RESULTS}

Tables 4 reports the results of Arellano-Bover/Blundell-Bond GMM estimation for various versions of equation (1). Table 4 illustrates the results of banks profitability represented by the return on assets as the dependent variable along with the independent variable of economic freedom and other control variables.

The empirical finding suggests that economic freedom has a positive and statistically significant impact on the profitability of Arab banks. Banks that operate in a business environment that protects investors and offers individuals the option to decide their own production and consumption decisions are able to generate higher income. Economic freedom is key to the creation of an environment that allows for a freedom to enter markets and compete, enhances the innovation and protects privately-owned property, as a result, they could gain faster economic growth. This result is in line with Sufian and Habibullah (2010) but in contrast with Sufian and Zulkhibri (2012) and Turgutluk (2014) who find the economic freedom variable is not statistically significant.

Table 4.

Banks Profitability and Economic Freedom Quality (System GMM Estimation)

\begin{tabular}{|c|c|c|c|c|c|c|c|}
\hline Independent & (1) & (2) & (3) & (4) & (5) & (6) & (7) \\
\hline Constant & $\begin{array}{c}1.173^{*} \\
(0.000)\end{array}$ & $\begin{array}{c}0.990^{*} \\
(0.000)\end{array}$ & $\begin{array}{c}0.141 \\
(0.491)\end{array}$ & $\begin{array}{c}0.540^{*} \\
(0.000)\end{array}$ & $\begin{array}{c}1.083^{*} \\
(0.000)\end{array}$ & $\begin{array}{c}1.987^{*} \\
(0.000)\end{array}$ & $\begin{array}{c}0.956^{*} \\
(0.000)\end{array}$ \\
\hline Economic freedom & & & & & $\begin{array}{c}0.042^{*} \\
(0.000)\end{array}$ & $\begin{array}{c}0.036^{*} \\
(0.018)\end{array}$ & $\begin{array}{l}0.029^{* *} \\
(0.053)\end{array}$ \\
\hline Bank size & $\begin{array}{c}0.306^{* * *} \\
(0.063)\end{array}$ & $\begin{array}{c}0.009^{*} \\
(0.019)\end{array}$ & $\begin{array}{l}0.002^{* *} \\
(0.033)\end{array}$ & & & & $\begin{array}{c}0.004^{*} \\
(0.000)\end{array}$ \\
\hline Liquidity & $\begin{array}{c}0.001^{*} \\
(0.009)\end{array}$ & $\begin{array}{c}0.001^{*} \\
(0.000)\end{array}$ & $\begin{array}{c}0.002^{*} \\
(0.000)\end{array}$ & $\begin{array}{c}0.007^{*} \\
(0.003)\end{array}$ & & $\begin{array}{c}0.001^{* * *} \\
(0.074)\end{array}$ & $\begin{array}{c}0.006^{*} \\
(0.004)\end{array}$ \\
\hline Overhead cost & & $\begin{array}{l}-0.065^{*} \\
(0.007)\end{array}$ & $\begin{array}{c}-0.063^{* *} \\
(0.028)\end{array}$ & $\begin{array}{c}-0.038^{* *} \\
(0.034)\end{array}$ & & & $\begin{array}{l}-0.227^{*} \\
(0.000)\end{array}$ \\
\hline Bank concentration & & & $\begin{array}{c}0.006^{*} \\
(0.000)\end{array}$ & $\begin{array}{c}0.003^{*} \\
(0.000)\end{array}$ & $\begin{array}{c}0.007^{* * *} \\
(0.077)\end{array}$ & $\begin{array}{c}0.007^{* * *} \\
(0.085)\end{array}$ & \\
\hline Income diversification & & $\begin{array}{c}0.002^{* * *} \\
(0.073)\end{array}$ & $\begin{array}{l}0.002^{* *} \\
(0.030)\end{array}$ & $\begin{array}{l}0.003^{* *} \\
(0.030)\end{array}$ & & & $\begin{array}{c}0.004^{*} \\
(0.000)\end{array}$ \\
\hline Credit risk & & & & $\begin{array}{c}-0.004^{* *} \\
(0.021)\end{array}$ & $\begin{array}{l}-0.022^{*} \\
(0.000)\end{array}$ & $\begin{array}{l}-0.018^{*} \\
(0.000)\end{array}$ & \\
\hline Cost efficiency & & & & & $\begin{array}{l}-0.006^{*} \\
(0.000)\end{array}$ & $\begin{array}{l}-0.007^{*} \\
(0.000)\end{array}$ & \\
\hline Capital strength & & & & & & & $\begin{array}{c}0.065^{*} \\
(0.000)\end{array}$ \\
\hline GFC & & & & & $\begin{array}{l}-0.099^{*} \\
(0.001)\end{array}$ & $\begin{array}{c}-0.069^{* *} \\
(0.030)\end{array}$ & $\begin{array}{c}-0.113^{* *} \\
(0.022)\end{array}$ \\
\hline GDP growth & $\begin{array}{c}0.005^{*} \\
(0.000)\end{array}$ & $\begin{array}{c}0.005^{*} \\
(0.009)\end{array}$ & $\begin{array}{c}0.008^{*} \\
(0.002)\end{array}$ & $\begin{array}{c}0.006^{*} \\
(0.001)\end{array}$ & $\begin{array}{c}0.010^{*} \\
(0.001)\end{array}$ & $\begin{array}{c}0.004^{* * *} \\
(0.072)\end{array}$ & $\begin{array}{c}0.025^{*} \\
(0.000)\end{array}$ \\
\hline Inflation & & & $\begin{array}{c}0.004^{*} \\
(0.000)\end{array}$ & $\begin{array}{l}0.006^{* *} \\
(0.028)\end{array}$ & & & \\
\hline Financial development & & & & & $\begin{array}{c}0.0003 \\
(0.825)\end{array}$ & $\begin{array}{c}-0.001 \\
(0.233)\end{array}$ & $\begin{array}{c}0.010^{*} \\
(0.000)\end{array}$ \\
\hline Observation & 247 & 212 & 165 & 161 & 87 & 91 & 87 \\
\hline
\end{tabular}




\begin{tabular}{lccccccc}
\hline \multicolumn{1}{c}{ Independent } & $\mathbf{( 1 )}$ & $\mathbf{( 2 )}$ & $\mathbf{( 3 )}$ & $\mathbf{( 4 )}$ & $\mathbf{( 5 )}$ & $\mathbf{( 6 )}$ & $\mathbf{( 7 )}$ \\
\hline \multirow{2}{*}{ Wald Chi2 } & $1533.07^{*}$ & $61.34^{*}$ & $93.20^{*}$ & $219.32^{*}$ & $134.48^{*}$ & $130.78^{*}$ & $232.13^{*}$ \\
& $(0.000)$ & $(0.000)$ & $(0.000)$ & $(0.000)$ & $(0.000)$ & $(0.000)$ & $(0.000)$ \\
Sargan test & 157.75 & 262.52 & 190.64 & 222.20 & 97.46 & 110.91 & 127.46 \\
& $(1.000)$ & $(0.812)$ & $(0.671)$ & $(0.146)$ & $(0.253)$ & $(0.235)$ & $(0.167)$ \\
Arellano-Bond test AR (1) & $-3.00^{*}$ & $-6.95^{*}$ & $-3.75^{*}$ & $-5.60^{*}$ & $-1.87^{* * *}$ & $-2.34^{*}$ & $-3.19^{*}$ \\
& $(0.036)$ & $(0.000)$ & $(0.000)$ & $(0.000)$ & $(0.061)$ & $(0.019)$ & $(0.001)$ \\
Arellano-Bond test AR (2) & 0.51 & 1.21 & -0.75 & 0.86 & -0.77 & -1.07 & -1.29 \\
& $(0.607)$ & $(0.226)$ & $(0.455)$ & $(0.392)$ & $(0.439)$ & $(0.284)$ & $(0.197)$ \\
\hline \hline
\end{tabular}

Note: return on assets is dependent variable. Arellano-Bover/Blundell-Bond econometric estimation. ${ }^{*},{ }^{* *},{ }^{* * *}$ denote significance at the $1 \%, 5 \%$ and $10 \%$ levels, respectively for p-values. Refer to Appendix Table A.1 for definition of variables. The lagged dependent variable is positive and significant in model 2, 4 and 6 only, the results are omitted for brevity.

The bank size variable has a significant and positive effect on the bank profitability. Banks with large financial assets can earn more profit as interest from loans is one of the main sources of a bank's profit. The explanation for this positive relationship between size and profit could be explained by the benefit from scale or scope economies. Moreover, large banks may be able to exert market power through stronger access for providing financial services or implicit regulatory protection, too-big-to-fail. Abnormal profits obtained through the exercise of market power in wholesale or capital markets may also contribute to a positive size-profitability relationship (Goddard et al., 2004). This result is in line with Agustini and Viverita (2012) and Hasanov et al., (2018).

The liquidity variable is positive and has a significant impact on profitability. Since high loans-to-deposits ratio refers to better asset-liability management, thus, higher the ratio indicates the bank is effectively utilizing its funds to generate higher profit. The banking system that has adequate amount of liquidity with high-level of intermediation capacity is operating more efficiently. Although it is possible for banks to face a problem associated with this scenario, with sound risk management the efficient manager can balance the funds in the bank to meet liquidity requirement based on future needs. This finding is in accordance with Abdelaziz et al., (2011) and Yao et al., (2018).

Overhead cost is negative and insignificant which implies that the reduced expenses ratio improves the efficiency of banks and consequently raise their profitability level. This result is consistent with Sun et al., (2017). Bank concentration is positive and significant which approves that the concentration means lower competition in the banking sector that can lead to high bank profitability. In such highly concentrated financial markets, banks tend to collude and therefore earn monopoly profits. This result indicates that the Arabic banking market is not fairly competitive. This result is consistent with Moutsianas et al., (2016) and Zheng et al., (2017).

The empirical results show that the income diversification variable is positive and significant which imply that the banks can generate a sizable portion of their total income from offbalance sheet activities (non-interest-bearing sources, including fees, commission, etc.), have better efficient profitability state. This result is in line with Islam and Nishiyama (2016) and Mohiuddin (2017).

The capital strength variable has a significant and positive effect on the bank profitability. Sufficient capital is providing better safety to the bank that follows better regulatory conditions if compared to those with lower capital strength. A higher capital ratio indicates that the bank is less risky and can borrow at lower interest rate for funding due to the reduction in the expected costs of financial distress, including bankruptcy. Moreover, banks with higher level of equity can absorb the potential losses more easily in order to continue a better economic life in the competitive 
hardship environment of an economy. This result is in line with Shahabadi and Samari (2013) and Combey and Togbenou (2017).

The cost efficiency variable is negative and significant which confirms that the efficiency in delivering banking services is considered as an important determinant of the profitability. Banks that have more efficient cost management can achieve higher profitability. This result is consistent with Liu and Wilson (2010), Sahyouni and Wang (2018)

The credit risk variable is negative and significant. This is consistent with the view that banks with higher ratio of loan loss provisions to total loans are less profitable and banks may incur additional expenses to intensify their monitoring and following up defaulters beside their loss in the payments of principal or interest. Thus, the greater the exposure of financial system to high risk loans, the higher would be the accumulation of unpaid loans and profitability would be lower. This finding is consistent with Gropper et al. (2015).

The GFC dummy is negative and significant which imply that the Arabic banks' profitability has been affected by the latest global financial crisis in 2008. The GFC caused collapsing and instability for the financial system over the world. Due to the GFC, the overall industry's business volume reduced and impacted the total banks operations, affecting borrowers' ability to repay loans, forcing the banks to reduce costs and make provisions for credit losses, hence, lowering the profitability. This result is in accordance with Agustini and Viverita (2012), Moutsianas et al., (2016), Caporale et al., (2016) and Islam and Nishiyama (2016), but in contrast with Sufian and Kamarudin, (2012) who find positive and insignificant impact and with Turgutluk (2014), positive but insignificant.

The GDP growth variable is positive and significant. This implies that banks that operate in countries with a high level of GDP growth rate are in a more profitable position. When the country is in prosperous economic conditions, this encourages the lending and borrowing activities with expecting a lower level of provisions. Moreover, banks can earn from dealing with more operational activities including non-interest bearing services during the economic growth. This in turn leads to more income resources for the bank and impact the profit positively. This finding is consistent with Coccorese and Girardone (2017) and with Yao et al., (2018).

The Inflation variable is positive and significant that means banks are able to manage the inflation expectation to increase revenue. Banks managers anticipated the inflation rate and they adjust their interest rates properly in the sense that their profit will be higher than what they will lose from the increase in costs caused by the inflation. This result is in line with Hasanov et al., (2018) and Antoun et al., (2018).

The financial development variable has mixed results, positive in model 5 and negative in model 6 but insignificant in both, however, only in model 7 is positive and significant which indicate that the demand for banking products and services increases in the economies that have well-developed banking sectors, so banks can increase their profitability with effective strategies. This result is in line with Tan and Floros (2012). However, it is in contrast with Coccorese and Girardone (2017) who find a negative and significant impact of financial development variable on bank profitability because operation in such highly competitive and crowded environment can cause a negative impact on the banks' margins and so the profit.

The Arellano and Bond test statistics for serial correlation and the Sargan test for overidentifying restrictions are reported in Tables 4. The Arellano and Bond AR (2) is insignificant, which implies that there is no second-order autocorrelation in the residuals. The Sargan test is insignificant, which means the instruments are not correlated with the residuals; thus, these instruments are valid. 


\section{CONCLUSION AND POLICY IMPLICATIONS}

This study empirically examines the impact of economic freedom on banks profitability in the Arab region. The study argues that better economic freedom quality that offers high protection is able to create a better business environment and impacts banks' profitability. The analysis is performed by employing the Arellano-Bover/Blundell-Bond GMM estimation in panel data comprising of 14 Arab countries over the period 1985-2016.

The results confirm that the economic redeem variable has a positive and significant impact on banks' profitability in Arab economies. This result suggests that less regulatory control enables the banks to engage in diversified activities and generate income from non-traditional sources. The results also show that bank size has a positive and significant impact on bank profitability, that is, banks that have relatively big size in the Arab region benefit from economies of scale. Banks costs and credit risk play a vital role in the profitability; thus, managers should efficiently monitor these variables. Moreover, the results show that banks with a more diversified income tend to have high profitability due to better asset quality and higher earnings. For economic variables, the findings show that the GFC has a negative impact on banks profit, whereas, both growth in GDP and inflation have a positive effect on bank profitability. Positive effect of inflation to bank profitability reflects the ability of bank managers to forecast inflation in their cost structure to realize profits.

The results of this study have several implications for policy makers. Banks managers should search for alternatives that increase the levels of bank capitalization, adopt innovative ways to increase the proportion of noninterest bearing income and effectively manage the deposits when converting them to profit generating activities in the assets, taking into the account liquidity levels. Furthermore, Arab countries need to enhance the local economic freedom quality by reforming regulations to facilitate business operations, encourage investments, and create a better efficient institutional environment that relies on free market mechanisms and a legal system that protects property and individual rights. These reforms and regulations must protect and guarantee investments in the region and should be coherent with global standards to increase confidence and reduce the risk of destabilizing the business environment. Governments need to employ efficient regulatory frameworks that encourage competition and boost the development of the banking sector and overall financial system. Governments and banks need to initiate research bodies that empirically investigate, study and better manage the factors that could impact profitability in the region so they can cooperate for future decisions.

\section{References}

Abdelaziz, H., Mouldi, D., Helmi, H. (2011) Financial Liberalization and Banking Profitability: A Panel Data Analysis for Tunisian Banks. International Journal of Economics and Financial Issues 1, pp. 19-32.

Abdullah, N., Tan, Y. (2017) Profitability of Commercial Banks revisited: New Evidence from oil and nonoil exporting countries in the MENA region. Investment Management and Financial Innovations 14, pp. 62-73.

Admati, R., DeMarzo, M., Hellwig, F., Pfleiderer, P. (2013) Fallacies, Irrelevant Facts, and Myths in the Discussion of Capital Regulation: Why Bank Equity is Not Socially Expensive. Rock Center for Corporate Governance at Stanford University, Working Paper No. 161. doi: http://dx.doi.org/10.2139/ssrn.2349739.

Agustini, A., Viverita, V. (2012) Factors Influencing the Profitability of Listed Indonesian Commercial Banks Before and During Financial Global Crisis. Indonesian Capital Market Review 4, pp. 29-40.

Akinkunmi, A. (2017) Regulatory Impact of Bank Performance in Nigeria: Application of Stochastic Frontier Analysis. Applied Economics and Finance 4, pp. 32-43.

Al Ismaily, N., Al-Busaidi, A. (2017) Economic Freedom of the Arab World: Annual Report. Fraser Institute. Retrieved from: http://www.freetheworld.com.

Alkhazaleh, M., Almsafir, M. (2014) Bank Specific Determinants of Profitability in Jordan. Journal of Advanced Social Research 4, pp. 01-20. 
Al-Omar, H., Al-Mutairi, A. (2008) Bank-Specific Determinants of Profitability: The case of Kuwait. Journal of Economic and Administrative Sciences 24, pp. 20-34.

Amba, M. S., Almukharreq, F. (2013) Impact of the Financial Crisis on Profitability of the Islamic Banks vs Conventional Banks - Evidence from GCC. International Journal of Financial Research 4, doi: https://doi. org/10.5430/ijfr.v4n3p83.

Antoun, R., Coskun, A., Georgievski, B. (2018) Determinants of financial performance of banks in Central and Eastern Europe. Business and Economic Horizons 14, pp. 513-529.

Arab Monetary Fund. (2013) Joint Arab Economic Report. Abu Dhabi, United Arab Emirates.

Arab Monetary Fund. (2016) Joint Arab Economic Report. Abu Dhabi, United Arab Emirates.

Arellano, M., Bond, S. (1991) Some tests of specification for panel data: Monte Carlo evidence and an application to employment equations. Review Economic Studites 58, pp. 277-297.

Arellano, M., Bover, O. (1995) Another look at the instrumental variable estimation of error-components models. Journal of Econometrics 68, pp. 29-51.

Asteriou, D., Pilbeam, K., Tomuleasa, I. (2016) The Impact of Economic Freedom, Business Regulation and Corruption on Bank Profitability and Bank Stability: Evidence from Europe. City Research Online: University of London Institutional Repository. Retrieved: http://openaccess.city.ac.uk/16839/.

Athanasoglou, P., Brissimis, N., Delis, D. (2008) Bank-specific, industry-specific and macroeconomic determinants of bank profitability. Journal of International Financial Markets, Institutions \& Money 18, pp. 121-136.

Bennaceur, S., Goaied, M. (2008) The Determinants of Commercial Bank Interest Margin and Profitability: Evidence from Tunisia. Frontiers in Finance and Economics 5, pp. 106-130.

Berger, A. N. (1995) The Profit-Structure Relationship in Banking--Tests of Market-Power and Efficient-Structure Hypotheses. Journal of Money, Credit and Banking 27, pp. 404-431.

Berger, A. N., Mester, L. J. (2003) Explaining the dramatic changes in performance of US banks: technological change, deregulation, and dynamic changes in competition. Journal of Financial Intermediation 12, pp. 57-95.

Busse, M., Groizard, J. (2008) Foreign direct investment, regulations and growth. World Economy 31, pp. 841-968.

Caporale, M., Lodh, S., Nandy, M. (2016) The performance of banks in the MENA region during the global financial crisis. German Institute for Economic Research, DIW Discussion Papers, No. 1580. Retrieved: http://hdl.handle. net/10419/142026.

Chan, S., Koh, Y. H., Zainir, F. (2015) Market structure, institutional framework and bank efficiency in ASEAN 5. Journal of Economics and Business 82, pp. 84-112.

Coccorese, P., Girardone, C. (2017) Bank capital and profitability: Evidence from a global sample. Essex Finance Centre, Working Papers 19480, University of Essex, Essex Business School. Retrieved: http://repository.essex. ac.uk/19480/.

Combey, A., Togbenou, A. (2017) The Bank Sector Performance and Macroeconomics Environment: Empirical Evidence in Togo. International Journal of Economics and Finance 9, doi:10.5539/ijef.v9n2p180.

Demirguc-Kunt, A., Huizinga, H. (2000) Financial structure and bank profitability. Policy Research Working Paper Series, Paper No. 2430, The World Bank. doi: http://dx.doi.org/10.1080/23311975.2016.1268356

Djalilov, K., Piesse, J. (2018) Determinants of bank profitability in transition countries: What matters most?. Research in International Business and Finance 38, pp. 69-82. DOI: http://openaccess.city.ac.uk/16839/.

ElKelish, W., Tucker, J. (2015) Property rights institutions and bank performance across Countries. Managerial Finance 41, pp. 80-101.

Francis, M. E. (2013) Determinants of Commercial Bank Profitability in Sub-Saharan Africa. International Journal of Economics and Finance 5, doi:10.5539/ijef.v5n9p134.

Garza-García, G. (2012) Determinants of bank efficiency in Mexico: a two-stage analysis. Applied Economics Letters 19, pp. 1679-1682.

Ghosh, S. (2016) Political transition and bank performance: How important was the Arab Spring?. Journal of Comparative Economics 44, pp. 372-382.

Goddard, J., Molyneux, P., Wilson, O. S. (2004) The profitability of European banks: a cross-sectional and dynamic panel analysis. The Manchester School, 72: pp. 363-381.

Gropper, D. M., Jahera Jr, J. S., \& Park, J. C. (2015) Political power, economic freedom and Congress: Effects on bank performance. Journal of Banking \& Finance, 60, pp. 76-92.

Gwartney, J., Lawson, R., Hall, J. (2014) Economic Freedom of the world: Annual report. Fraser Institute. Retrieved from: http://www.freetheworld.com.

Gwartney, J., Lawson, R., Hall, J. and Murphy, R. (2018) Economic Freedom of the world: Annual report. Fraser Institute. Retrieved from: http://www.freetheworld.com.

Hasanov, F., Bayramli, N., Al-Musehel, N. (2018) Bank-Specific and Macroeconomic Determinants of Bank Profitability: Evidence from an Oil-Dependent Economy. International Journal of Financial Studies 6 , doi:10.3390/ijfs6030078.

Islam, S., Nishiyama, S. (2016) The Determinants of Bank Profitability: Dynamic Panel Evidence from South Asian Countries. Journal of Applied Finance \& Banking 6, pp. 77-97. 
James, G., Witten, D., Hastie, T., Tibshirani, R. (2015) An Introduction to Statistical Learning with Applications in R. New York: Springer.

Kuhn, M., Johnson, K. (2013) Applied Predictive Modeling. New York: Springer.

Lema, Z. (2017) Determinants of bank technical efficiency: Evidence from commercial banks in Ethiopia. Cogent Business \& Management 4, pp. 1-13, doi: https://doi.org/10.1080/23311975.2016.1268356.

Liu, H., Wilson, O.S. (2010) The profitability of banks in Japan. Applied Financial Economics 20, pp. 851-1866.

Logan, T. (2016) Determinants of profitability of financial institutions in Latin America and the Caribbean. The Journal of Developing Areas 50, pp. 345-362.

Mohiuddin, M. (2017) The Determinants of Profitability of Private Banks in Bangladesh: An Empirical Analysis. Journal of Social Sciences 11, pp. 141-172.

Mokni, S., Rachdi, H. (2014) Assessing the bank profitability in the MENA region A comparative analysis between conventional and Islamic bank, International Journal of Islamic and Middle Eastern Finance and Management 7 , pp. 305-332.

Moutsianas, A., Kosmidou, K. (2016) Bank earnings volatility in the UK: Does size matter? A comparison between commercial and investment banks. Research in International Business and Finance 38, pp. 137-150.

Murthy Y, R., Al-Muharrami, S. (2014) Financial Sector Development and the Determinants of Bank Profitability: A GCC Panel Study. International Research Journal of Finance and Economics, doi: 10.2139/ssrn.2664577.

Reddy, S. (2011) Determinants of Commercial Banks Profit Ability in India: A Dynamic Panel Data Model Approach. Pakistan Journal of Applied Economics 21, pp. 15-36.

Rekik, M., Kalai, M. (2018) Determinants of banks' profitability and efficiency: Empirical evidence from a sample of Banking Systems. Journal of Banking and Financial Economics 1, pp. 5-23.

Sahyouni, A., Wang, M. (2018) The determinants of Bank Profitability: Does Liquidity Creation matter?. Journal of Economics and Financial Analysis 2, pp. 61-85.

Shahabadi, A., Samari, H. (2013) The Effect of Economic Freedom on Bank Performance. Iranian Journal of Economic Studies 2, pp. 123-142.

Spathis, C., Kosmidou, K., Doumpos, M. (2002) Assessing profitability factors in the Greek banking system: A multicriteria methodology. International Transactions in Operational Research 9, pp. 517-530.

Sufian, F., Kamarudin, F. (2012) Bank-Specific and Macroeconomic Determinants of Profitability of Bangladesh's Commercial Banks. Bangladesh Development Studies 35, pp. 1-29.

Sufian, F. (2012) Determinants of bank profitability in developing economies: empirical evidence from the South Asian banking sectors. Contemporary South Asia 20, pp. 375-399.

Sufian, F., Habibullah, S. (2009) Determinants of bank profitability in a developing economy: Empirical evidence from Bangladesh. Journal of Business Economics and Management 10, pp. 207-217.

Sufian, F., Habibullah, S. (2010) Has economic freedom fostered bank performance? Panel evidence from China. China Economic Journal 3, pp. 255-279.

Sufian, F., Zulkhibri, M. (2012) The Nexus between Economic Freedom and Islamic Bank Profitability in the MENA Banking Sectors. Global Business Review 16, pp. 58S-81S.

Sun, H., Mohamad, S., Ariff, M. (2017) Determinants driving bank performance: A comparison of two types of banks in the OIC. Pacific-Basin Finance Journal 42, pp. 193-203.

Tan, Y., Floros, C. (2012) Bank profitability and GDP growth in China: a note. Journal of Chinese Economic and Business Studies 10, pp. 267-273.

Turgutluk, E. (2014) Dynamics of Profitability in the Turkish Banking Industry.' Ege Akademik Bakış 14, pp. 43-52.

Yao, H., Haris, M., Tariq, G. (2018) Profitability Determinants of Financial Institutions: Evidence from Banks in Pakistan. International Journal of Financial Studies 6, pp. 1-28. doi:10.3390/ijfs6030078.

Zheng, C., Rahman, M., Begum, M. (2017) Capital Regulation, the Cost of Financial Intermediation and Bank Profitability: Evidence from Bangladesh. Journal of Risk and Financial Management 10, pp. 1-24. doi:10.3390/ jrfm10020009. 


\section{APPENDIX}

Table A.1.

Data definition and sources

\begin{tabular}{|c|c|c|}
\hline Variable & Definition & Source \\
\hline $\begin{array}{l}\text { Return } \\
\text { on assets }\end{array}$ & $\begin{array}{l}\text { It is measuring the banks' performance and calculated as } \\
\text { the banks' after-tax net income to yearly averaged total } \\
\text { assets (percentage). }\end{array}$ & $\begin{array}{l}\text { World Bank's Global Financial } \\
\text { Development Database. }\end{array}$ \\
\hline $\begin{array}{l}\text { Economic } \\
\text { freedom }\end{array}$ & $\begin{array}{l}\text { It measuring the level of economic freedom. High score } \\
\text { indicates high freedom. }\end{array}$ & $\begin{array}{l}\text { Author's own calculations based, } \\
\text { The Fraser Institute. }\end{array}$ \\
\hline Bank size & $\begin{array}{l}\text { It is the total assets held by deposit money banks as a } \\
\text { share of GDP (percentage). }\end{array}$ & $\begin{array}{l}\text { World Bank's Global Financial } \\
\text { Development Database. }\end{array}$ \\
\hline Liquidity & $\begin{array}{l}\text { It is the ratio of loans as a share of total deposits } \\
\text { (percentage). }\end{array}$ & $\begin{array}{l}\text { World Bank's Global Financial } \\
\text { Development Database. }\end{array}$ \\
\hline Overhead cost & $\begin{array}{l}\text { It is operating expenses of a bank as a share of the value } \\
\text { of all assets held (percentage). }\end{array}$ & $\begin{array}{l}\text { World Bank's Global Financial } \\
\text { Development Database. }\end{array}$ \\
\hline $\begin{array}{l}\text { Bank } \\
\text { concentration }\end{array}$ & $\begin{array}{l}\text { It is the assets of five largest banks as a share of total } \\
\text { commercial banking assets }\end{array}$ & $\begin{array}{l}\text { World Bank's Global Financial } \\
\text { Development Database. }\end{array}$ \\
\hline $\begin{array}{l}\text { Income } \\
\text { diversification }\end{array}$ & $\begin{array}{l}\text { It is bank's income that has been generated by noninterest } \\
\text { related activities as a percentage of total income } \\
\text { (percentage). }\end{array}$ & $\begin{array}{l}\text { World Bank's Global Financial } \\
\text { Development Database. }\end{array}$ \\
\hline Credit risk & $\begin{array}{l}\text { It is the ratio of defaulting loans to total gross loans } \\
\text { (percentage). }\end{array}$ & $\begin{array}{l}\text { World Bank's Global Financial } \\
\text { Development Database. }\end{array}$ \\
\hline Cost efficiency & $\begin{array}{l}\text { It is operating expenses of a bank as a share of operating } \\
\text { income (percentage). }\end{array}$ & $\begin{array}{l}\text { World Bank’s Global Financial } \\
\text { Development Database. }\end{array}$ \\
\hline Capital strength & $\begin{array}{l}\text { It is the ratio of bank capital and reserves to total assets } \\
\text { (percentage). }\end{array}$ & $\begin{array}{l}\text { World Bank's Global Financial } \\
\text { Development Database. }\end{array}$ \\
\hline $\begin{array}{l}\text { Global financial } \\
\text { crisis (GFC) }\end{array}$ & $\begin{array}{l}\text { Dummy equal to } 1 \text { for the years } 2009 \text { to } 2016 \text { and zero } \\
\text { otherwise. }\end{array}$ & Authors own calculations. \\
\hline GDP growth & $\begin{array}{l}\text { It is the percentage growth of gross domestic production } \\
\text { (GDP) (percentage). }\end{array}$ & $\begin{array}{l}\text { World Bank's World } \\
\text { Development Indicators. }\end{array}$ \\
\hline Inflation & $\begin{array}{l}\text { rate is the annual percentage change in consumer price } \\
\text { index }(\mathrm{CPI}) \text {. }\end{array}$ & $\begin{array}{l}\text { World Bank, World Development } \\
\text { Indicators. }\end{array}$ \\
\hline $\begin{array}{l}\text { Financial } \\
\text { development }\end{array}$ & $\begin{array}{l}\text { It is bank domestic credit to private sector as percentage } \\
\text { of GDP (percentage). }\end{array}$ & $\begin{array}{l}\text { World Bank’s Global Financial } \\
\text { Development Database. }\end{array}$ \\
\hline
\end{tabular}

